\title{
Microlending: What Business Can Do To Facilitate Community-Based Growth
}

\author{
Mackenzie M. Festa, West Virginia University, USA \\ Alan J. Wilson, West Virginia University, USA \\ Presha E. Neidermeyer, Ph.D., CPA, West Virginia University, USA
}

\begin{abstract}
Billions of dollars have been expended in foreign assistance throughout the third world, with much of this aid being provided by the not-for-profit community. While frequently effective in facilitating short-term benefits, these projects often do not improve the continuing living conditions for the residents of the community. Not-for-profits generally are in the business of short-term crisis relief; consequently, they do not have a focus on job provisions in the affected community that would increase their living standards in the long-term. Entrepreneurs, on the other hand, are in the business of job creation, which not only provides long-term benefits for the entrepreneur, but also for the entire community. Microlending, a term coined originally by Muhammad Yunus to describe very small loans made in third-world countries, has had an enormous impact on the lives of entrepreneurs, their families, and their communities. Many notfor-profits may wish to employ the techniques illustrated by Yunus and other successful microlending institutions. They may find the task overwhelming, however, without employing business professionals, whose services can be costly. For not-for-profits who might be interested in starting such a program, this paper will describe the process of microlending, articulate methods of selecting a loan recipient, and show mechanisms for documenting a microloan.
\end{abstract}

Keywords: microlending, community lift, and microfinance institutions

\section{INTRODUCTION}

ith an overarching goal to rid the world of poverty, many microlending institutions seek to foster
entrepreneurship as the means of economic sustainability as it applies to marginalized members of
society, particularly women. While microlending was initiated outside of the United States, the basic concept of lending to the poor still has world-wide relevance and is a formidable alternative to government aid.

Most microfinance institutions (MFIs) operate as not-for-profit entities and must seek the guidance of business professionals in order to develop sustainable microloan centers. (Mersland, 2009) The benefits of a MFI go beyond the extension of credit. In Yunus' seminal microloan project, the Grameen bank provided education in business practices including expectations for and means of accomplishing load repayment, and assisted, through the formation of borrower groups, with the mentoring of individual business owners. Microlending is not a handout, but rather an opportunity to embrace capitalism and remove one's self from poverty. program.

This paper discusses a number of factors that are important to consider when planning a microlending

\section{GOALS}

The goal of most microlending institutions is to achieve an increase in a community's standard of living through use of strategic loans made to entrepreneurs and the ensuing business ideas. This goal drives the selection of the loan recipients and projects in which the microfinance institutions should invest. The projects that are funded should be sustainable, fulfill a need in the community, and have the potential to broaden the economic base of the community. 
Beyond just furnishing loans, many microfinance institutions provide educational opportunities, health care initiatives, and improvements in infrastructure. These are the foundations on which a stable economic environment can be built.

\section{SUSTAINABILITY}

The first goal of any MFI should be to establish its independence and function economically on its own operations. Even though they are established with good intentions, many MFIs fail to earn revenues capable of supporting the initiatives of the firm. Through proper project selection and quality candidate training, loan interest and deposits can be made to fund all MFI projects. ${ }^{1}$

Similar to other financial institutions, microfinance institutions wield great authority in directing the flow of capital. With every loan decision, the regional and global economy is impacted. At the community level, microloan decisions can determine the economic producers of an area.

With such influence comes responsibility to act in the interests of the whole. Encouraging local donations or allocating a portion of interest revenue may be sources of funding for a community savings program. The development of such a program establishes a public reserve of cash and serves to improve local stability. This cash reserve is funded with the intent of assisting others when needs arise. In the event of destruction via weather, war, or accidents, the community reserve would serve the needs of any struggling populace.

The strategy for granting microloans should be aligned so as to provide for long-term relief from poverty. By granting loans to sustainable, long-term projects, growth is possible. One of the biggest problems faced by inexperienced entrepreneurs is the ability to differentiate between capital and profit. In order to ensure that a business is sustainable in the long-run, the entrepreneur should not "consume his inventory", lest the business fail, and the microfinance institution not be able to collect on the loan. In a recent study of microloans made in Bangladesh (Molla, Alam, \& Wahid, 2008), the investigators found that a high proportion of loans were used for personal consumption and debt repayment, rather than investing in activities that contribute to overall productivity.

\section{EDUCATION}

One of the largest results from microfinance is the establishment of accountability among borrowers. With government aid, monies are generally not paid back and the beneficiary does not have a structured opportunity to develop or demonstrate a sense of responsibility for those funds. With microloans, the borrower enters into a contractual agreement in which scheduled payback is required. Through successful repayments, the lender earns interest revenue and the borrower improves their self-reliance. The borrower's change in self-efficacy illustrates a profound effect of microlending.

Borrowers, particularly those who are applying for their first loan, often lack the business training necessary to fully appreciate their responsibilities. The loan cycle operates more efficiently when both parties understand the process, so educational opportunities are an important component of the microlending process. Central to any such program should be a discussion regarding the differences between debt and equity financing. Other discussion topics may include general banking, business plans, marketing, shipping, and transaction recording. A detailed list of discussion topics and their components is available from the authors upon request.

In addition to business training, the educational efforts should include general education, and should address proper health practices in particular. Encouraging development of and access to health-maintaining resources is essential to progress in a developing country. Even basic life skills, such as check writing, which are taken for granted within industrialized countries, must also be gradually introduced through successive educational sessions.

\footnotetext{
${ }^{1}$ In cases where government subsidies and concessional lines of credit finance a microfinance initiative, the MFI presents borrowers with greater instability. Macroeconomic variables not only affect the borrower, but also the lender and its source of funding. The prevalence of subsidies addresses microfinance in the short-term, but fails to provide for sustainable, long-term growth. (Yaron, Benjamin, \& Charitonenko, 1998)
} 


\section{LENDER PRESENCE}

Lenders hold the keys to the safe. They are responsible for determining the worthiness of a potential client and the viability of the loan. While the processing for a loan can be completed anywhere with internet access, a physical presence within the community improves the likelihood that the borrower will not default on the loan. A brick and mortar banking establishment is not necessarily required, but a community presence is helpful in promoting the culture needed for load payment. The lender would be able to offer continuing education to the borrowers, react rapidly to changing conditions within the community, and mentor loan recipients in business practices. These services, critical to the success of the process, would be much more difficult, if not impossible, for a remotely based institution.

\section{DOCUMENTATION}

The documentation portion of the microlending process is the most formalized section. It requires the applicant to complete the requisite paperwork from the lending institution. While not completely standardized, most loans will require completion of an application document, which will include the purpose of the loan, a history of the borrower, and formal financial statements portraying the financial and collateral positions of the applicant. An example of a formal application including personal financial statements for a borrower can be obtained upon request from the authors. Given the smaller dollar amounts for loans required by borrowers in a microlending environment, these financial statements may either be abbreviated or modified to suit the needs of the lending institution. Critically important is to have enough information to evaluate the loan project and the borrower objectively so as to ensure (to the extent possible) that repayment will be made to the lending institution so that future loans can be made. In areas where FICO scores are available, a form authorizing the lender to review such information is required.

Given technological advances, the application can take place over disparate geographical locales. Processing, for example, could occur far afield from the borrowing and project site. In microlending, however, personal interviews may be very helpful, and thus ought to be considered prior to making the loan decision. References will become a significant contributing factor; in some regions, a solid reputation may be the best collateral.

Microloans may be identified by their placement in one of two categories: Necessity Entrepreneur and Emerging Stable. These two categories provide a guideline when looking at sustainability. The necessity entrepreneur normally owns an informal business in a poverty-stricken area, and the goal with this type of loan would be to help provide the funds needed to grow the business, and provide the owner with a basic education concerning business strategy. Emerging stable loans, on the other hand, are made in order to facilitate the growth of an existing company. These may fund a company's growth into another area, or the hiring more employees, for example. This type of loan often provides the best return in terms of poverty relief (Brijlal, 2008).

A potential pit fall in microlending is that the funds go toward paying down current debt or are used for personal living expenses. These uses don't contribute to improving the overall economic situation within the community, which is one of the goals of a microloan program. Past loan institutions have had their payback ratios scrutinized because they included a higher portion of loans for such purposes. Sustainable microlending focuses on poverty relief through job creation, not through financed consumption.

Once a microloan has been granted, the lending institution should act as any commercial lender would and maintain contact with the borrower as well as monitor the progress of the business entity. Loan proceeds should be accounted for by the borrower with loan benefits evidenced by visible progress. A goal of the contact between a lender and a borrower is to promote timely repayment as payment collection is a key component during the loan's lifecycle.

In industrialized countries with significant measures of security, monthly payment dates typically suffice. In underdeveloped countries or neglected communities located within industrialized countries, any cash or valuable asset may be vulnerable to theft. In instances where estimated exposure to loss is high, more frequent collection 
periods are recommended to protect the lender and the borrower. Access to a deposit institution provides a new level of security to depressed regions.

As a method to ensure proper identification in an absence of a government regulated medium, institution issued ID cards serve as a solution. With low cost cards and reader systems, the lending institution can affordably implement IDs with technology to simplify the process of recording received loan payments.

\section{CONCLUSION}

The process of microlending involves a continuous cycle of activities to recruit, select, and manage client relationships. Frequent coaching and client interaction are essential to successful economic development. Any microfinance institution should set goals for development and measure their progress throughout each loan cycle. To fully establish a sustainable and stable presence in any region, the microfinance institution must reach a stage of independent financing in which net interest margin covers the expenses of the institution and provides funds to generate new loans.

Microfinance initiatives exert a great deal of influence on the people of any selected region. By offering access to credit, programs to create infrastructure, and opportunities to develop and utilize local resources, microlending changes lives. With the proper training and careful loan selection, microfinance can offer those in poverty an opportunity to provide for their family and offer the next generation a better life.

\section{AUTHOR INFORMATION}

Mackenzie M. Festa is credit analyst at Centra Bank, Inc., the third fastest growing private bank in the United States. He is a May 2010 graduate of West Virginia University with a Bachelor of Science in Business Administration. Mackenzie's research interests include commercial real estate and banking. He is the past president of Students In Free Enterprise (SIFE).

Alan J. Wilson is a Senior Accounting major at West Virginia University, and is a Management Intern at WesBanco Bank. He is a member of the West Virginia University President's List, is the current President of the WVU Accounting Club, and is the Treasurer of Students in Free Enterprise (SIFE). Alan's research interests include the areas of banking, personal financial planning, and forensic accounting.

Dr. Presha E. Neidermeyer is a faculty member in the Division of Accounting within West Virginia University's College of Business and Economics. She is a behavioral researcher focusing on current events with particular emphasis on the impact of culture on decision-making. She is the co-author of Use What You Have: Resolving the HIV/AIDS Pandemic. Her teaching specialties include: financial and international accounting. She is an active participant in various organizations benefiting charities in Africa and has led multiple business-student teams to Africa.

\section{REFERENCES}

1. Berkman, E. (2007). Microloans as a Community Reinvestment Act Compliance Strategy. NYU Journal of Law \& Business, 329-351.

2. Brijlal, P. (2008). Business Development Service: Addressing The Gap In Western Cape, South Africa. International Business \& Economics Research Journal, 49-53.

3. Mersland, R. (2009, February). The Cost of Ownership in Microfinance Organizations. World Development, pp. 469-478.

4. Molla, R. I., Alam, M. M., \& Wahid, A. N. (2008). Questioning Bangladesh's Microcredit. Challenge, 51 (6), 113-121.

5. Richardson, M. (2009). Increasing Microlending Potential in the United States Through a Strategic Approach to Regulatory Reform. Journal of Corporation Law , 924-942.

6. Seel, S.-J. (2008/2009, Winter). Microfinance for the Poor: A Sustainable Solution To Poverty? Retail Digest, pp. 20-23. 
7. Surowiecki, J. (2008, March 17). What Microloans Miss. Retrieved March 5, 2010, from The New Yorker: http://www.newyorker.com/talk/financial/2008/03/17/080317ta talk_surowiecki

8. Yaron, J., Benjamin, M., \& Charitonenko, S. (1998). Promoting Efficient Rural Financial Intermediation. The World Bank Research Observer 13 (2), 147-170.

9. Yunus, M. (2003). Banker to the Poor: Micro-Lending and the Battle against World Poverty . New York: Public Affairs.

10. Yunus, M. (2007). Creating a World Without Poverty: Social Business and the Future of Capitalism. New York: Public Affairs. 
NOTES 